\title{
WHAT IS THE "FAIRNESS" IN CASE OF APPLYING FOR THE RETROACTIVE THERAPEUTIC USE EXEMPTION IN SPORTS?
}

\author{
Ilia Vasilyev \\ Ph.D, Associate Professor \\ Law School \\ Saint Petersburg State University \\ Email: i.vasilev@spbu.ru
}

\begin{abstract}
Article 4.3 of the WADA International Standard for Therapeutic Use Exemptions (ISTUE) 2019 edition provides four alternative reasons for the retroactive Therapeutic Use Exemption (TUE) that an athlete can prove. One amongst them is a "fairness criterion", applying when other criteria could not be meet in case of the sportsmen.

The process of obtaining the retroactive TUE on fairness criterion raises a question in context the "fair" and "unfair". This dilemma could raise the ground of factual circumstances in the particular case of an anti-doping violation. When the sportsman does not have any other criterion for the retroactive TUE, he or she may attempt to argue the fairness in the occasion. Although the Anti-Doping Organizations have the right to decide the content of "fairness", is it impossible for the Court of Arbitration for Sport (CAS) as a non-professional body on medical issues?

The WADA regulations give us another example of using fairness as a turning point in cases of sportsman's anti-doping compliance procedures. Thus the articles 10.8 and 10.11.3.4 of the WADA Code 2015 are used as the "fairness exception" for excluding the presumption of disqualifying the sportsmen's results, points, medals, and prizes in case of anti-doping liability.

To understand what the "fairness" is in cases of anti-doping offenses we turn our view on the CAS practice on issues of the "fairness exception" and "fairness criterion". In conclusion, we could summarize the CAS approaches to the content of fairness in cases, connected with the process of granting the retroactive TUE.
\end{abstract}

Keywords: WADA International Standard for Therapeutic Use Exemptions, fairness criterion, WADA Code, fairness exception, Court of Arbitration for Sport (CAS) practice. 


\section{Introduction}

The natural justice principle requires that fairness should be observed as a substantial and procedural requirement in cases of liability, including the disciplinary liability in sport. This requirement determines using the fundamental rights and principles in the process of investigating and resolving anti-doping offenses. From the other point of view, the "fairness criterion" and "fairness exception" are more substantial than procedural. At the same time, "fairness" is closely connected with the procedural guarantees - the right to argue the necessity of another way of deciding in your situation.

The anti-doping organization has right to provide retroactive TUE on different criteria, essential including the fairness: "It is agreed, by WADA and by the AntiDoping Organization to whom the application for a retroactive TUE is or would be made, that fairness requires the grant of a retroactive TUE" (Art. 4.3 (d) (emphasis added $)^{1}$. The official comment to 4.3(d): IfWADA and/or the Anti-Doping Organization do not agree to the application of Article 4.3(d), that may not be challenged either as a defense to proceedings for an anti-doping rule violation, or by way of appeal, or otherwise ${ }^{2}$. In certain situations, only this basis leaves the athlete with a chance to receive the retroactive TUE.

In comparison a new 2021 edition of the WADA ISTUE gives us slightly a new formula of fairness criterion basis for granting TUE: "In exceptional circumstances and notwithstanding any other provision in this International Standard for Therapeutic Use Exemptions, an Athlete may apply for and be granted retroactive approval for his/ her Therapeutic Use of a Prohibited Substance or Prohibited Method if, considering the purpose of the Code, it would be manifestly unfair not to grant a retroactive TUE. For International-Level Athletes and National-Level Athletes, an Anti-Doping Organization may grant an Athlete's application for a retroactive TUE pursuant to this Article only with the prior approval of WADA (and WADA may in its absolute discretion agree with or reject the Anti-Doping Organization's decision)" (emphasis added $)^{3}$.

Differences in the 2021 edition were made, firstly, for stipulating the Wada Code purpose as a legitimate certain direction for considering a question of fair or unfair in the situation of a sportsman and, secondly, for adding a "manifestly" to enhance the content of unfairness. Although these amendments have not constructed a concept of fairness, this could be mentioned as a step backward and then forward in comparison with the previous edition of the WADA ISTUE. "Manifestly" means that Anti-Doping Organization has to answer a question, does level of unfairness is crucial or not for receiving the retroactive TUE case-by-case basis. This discretion seems us a dangerous but also a necessary decision. That is why we said about the step backward and forward simultaneously - the dimension is in hands of the AntiDoping Organization. Then, the 2021 edition of the WADA ISTUE emphasized a role not only of the administrative body of the international sports federation or other 
Anti-Doping Organizations but also the Court of Arbitration for Sport (CAS) as an appeal instance.

However, the fairness has been used by WADA not only in ISTUE but also in the WADA Code. 2015 and 2021 editions of the WADA Code propose similar "fairness exception" when the fair dictates saving the results, points, medals, and prizes obtained by the sportsman after the date of sample collection until the start of the period of disqualification. The fairness exception is also used while the AntiDoping Organization answers the question to disqualify or not the results of the team in cases of liability for anti-doping violations for one of its athletes. In comparison, both editions of the WADA Code put forward identical norms on the mentioned issue of fairness (see below).

\begin{tabular}{|c|c|}
\hline WADA Code 2015 & ode 2021 \\
\hline $\begin{array}{l}\text { 10.8. In addition to the automatic } \\
\text { Disqualification of the results in the } \\
\text { Competition which produced the positive } \\
\text { Sample under Article 9, all other competitive } \\
\text { results of the Athlete obtained from the date } \\
\text { a positive Sample was collected (whether } \\
\text { In-Competition or Out-of-Competition), or } \\
\text { other anti-doping rule violation occurred, } \\
\text { formulate through the commencement of } \\
\text { any Provisional Suspension or Ineligibility } \\
\text { period, shall, unless fairness requires } \\
\text { otherwise, be Disqualified with all of the } \\
\text { resulting Consequences including forfeiture } \\
\text { of any medals, points and prizes }{ }^{1} \text { (emphasis } \\
\text { added). }\end{array}$ & $\begin{array}{l}\text { 10.10. In addition to the automatic } \\
\text { Disqualification of the results in the } \\
\text { Competition which produced the positive } \\
\text { Sample under Article 9, all other competitive } \\
\text { results of the Athlete obtained from the date } \\
\text { a positive Sample was collected (whether In- } \\
\text { Competition or Out-of-Competition), or other } \\
\text { antidoping rule violation occurred, through } \\
\text { the commencement of any Provisional } \\
\text { Suspension or Ineligibility period, shall, } \\
\text { unless fairness requires otherwise, be } \\
\text { Disqualified with all of the resulting } \\
\text { Consequences including forfeiture of any } \\
\text { medals, points and prizes }{ }^{2} \text { (emphasis added). }\end{array}$ \\
\hline $\begin{array}{l}\text { 10.11.3.4. In Team Sports, where a } \\
\text { period of Ineligibility is imposed upon a } \\
\text { team, unless fairness requires otherwise, the } \\
\text { period of Ineligibility shall start on the date } \\
\text { of the final hearing decision providing for } \\
\text { Ineligibility or, if the hearing is waived, on } \\
\text { the date Ineligibility is accepted or otherwise } \\
\text { imposed. Any period of team Provisional } \\
\text { Suspension (whether imposed or voluntarily } \\
\text { accepted) shall be credited against the total } \\
\text { period of Ineligibility to be served }{ }^{3} \text { (emphasis } \\
\text { added). }\end{array}$ & $\begin{array}{l}\text { 10.13.2.4. In Team Sports, where a } \\
\text { period of Ineligibility is imposed upon a } \\
\text { team, unless fairness requires otherwise, the } \\
\text { period of Ineligibility shall start on the date } \\
\text { of the final hearing decision providing for } \\
\text { Ineligibility or, if the hearing is waived, on } \\
\text { the date Ineligibility is accepted or otherwise } \\
\text { imposed. Any period of team Provisional } \\
\text { Suspension (whether imposed or voluntarily } \\
\text { accepted) shall be credited against the total } \\
\text { period of Ineligibility to be served } \text { (emphasis }^{4} \\
\text { added). }\end{array}$ \\
\hline
\end{tabular}




\begin{tabular}{|c|c|}
\hline $\begin{array}{l}\text { EXAMPLES OF THE APPLICATION } \\
\text { OF ARTICLE } 10 . \\
\text { 6. According to Article 10.8, all results } \\
\text { obtained by the Athlete subsequent to the } \\
\text { date of the Sample collection until the start } \\
\text { of the period of Ineligibility would also } \\
\text { be Disqualified unless fairness requires } \\
\text { otherwise }^{5} \text { (emphasis added). }\end{array}$ & $\begin{array}{l}\text { EXAMPLES OF THE APPLICATION } \\
\text { OF ARTICLE } 10 \text {. } \\
\text { 6. According to Article 10.8, all results } \\
\text { obtained by the Athlete subsequent to the } \\
\text { date of the Sample collection until the start } \\
\text { of the period of Ineligibility would also } \\
\text { be Disqualified unless fairness requires } \\
\text { otherwise }^{6} \text { (emphasis added). }\end{array}$ \\
\hline
\end{tabular}

The legal positions of the CAS will allow us to understand what should be "fair" and "unfair" from the WADA Code and WADA ISTUE in cases of anti-doping violations. We will also focus on the question of whether it is possible to draw an analogy within the framework of the WADA Code to particular occasions. Finally, we offer a list of "fairness" examples.

\section{The "fairness exception" in disqualifying the sportsman's results, ranking points, and returning the prize money.}

We wish to point out that "fairness" as an exception in disqualifying the sportsman's results, ranking points, and returning the prize money is a threat to some Panels of the CAS. Sometimes fairness interpreted strictly and formally, which is not the optimal solution. The mentioned fairness exception had been made in the WADA Code and then was implemented in regulations of Anti-Doping Organizations. This was done not for the checkmark. The Anti-Doping Organizations must investigate in every case is it possible to use fairness as a point for the balance in the global sport when the sportsman is fully responsible for his professional life in connection with the risks of anti-doping regulations infringements. But also around are enough factual circumstances which may affect the sportsman and then it is quite necessary to answer a question: could it be fair not to disqualify the sportsman's results, ranking points and returning the prize money. As for us, it cannot be ruled out that the only liability of the sportsman for anti-doping violations is an adequate measure without any accompanying negative aftermaths. Although, the strict approach of the CAS to the interpretation of fairness exception is still actual and we demonstrate it on the example of two cases.

Firstly, in the CAS 2017/A/5301, the sportsman argued that it would be unfair to annul her previous results due to anti-doping violations. In this case, the International Tennis Federation (ITF) pointed out the beginning of the period of the disqualification of results from the date of the sportsman's date of sample collection. As sportsman submitted, "the inadvertent ingestion of letrozole was not intended to enhance performance nor did it do so and she did not use letrozole on a regular basis" and her "next doping test was negative and none of her subsequent results have been affected by the ingestion of letrozole. The next match took place on 8 March 
2017, 20 days after her positive test"4. Accordingly, there was no unfairness to other sportsmen due the using the prohibited substance. Nevertheless, the CAS did not accept the proposing approach. The Panel put one's mind to the fact that the fairness exception was constructed for occasions when "during a phase of non-suspension, performance-enhancing effects were no longer present". Then for exception's applying it is the sportsmen's burden of proof to present evidence, proving factual circumstances of absent the performance-enhancing effects in the period before the date of sample collection. The only key for fairness exception is to find evidence for the non-performance impact of the prohibited substance or the prohibited method.

Secondly, in CAS 2016/O/4464 the CAS chose a dual position on the issue of the fairness exception. On the one hand, the Panel understood that the period of disqualification of the sportsman's results seemed long enough and then "must be deemed excessive in terms of proportionality". At the same time, the Panel gave us an explanation of the strict approach: "not to disqualify results that have been achieved by using a prohibited substance or prohibited method cannot be considered as fair concerning other athletes that competed against the Athlete during this period" (emphasis added) ${ }^{7}$. So, the CAS perfectly understands the disproportionality of the chosen period of disqualification of the sportsman's results because of its excessiveness. For the CAS this strictest approach is motivated by the aim of the antidoping sanctions - to remove cheating records from the history and correct unfair results in favor of honest sportsmen. Say some words about this case. According to the CAS, the sportsman had used a sophisticated plan, scheme, and tactics to hide the use of a prohibited substance or prohibited method. In this situation, only the ignoring the fairness exception could maintain a balance between the aims of deterrence of anti-doping offenses and the measures used for it $^{8}$. A similar conclusion was made

4 Arbitrations CAS 2017/A/5301 Sara Errani v. International Tennis Federation (ITF) \& CAS 2017/A/5302 National Anti-Doping Organisation (Nado) Italia v. Sara Errani and ITF, award of 8 June 2018, para. 100. http://jurisprudence.tas-cas.org/Shared\%20Documents/5301,\%205302.pdf (date accessed: June 13, 2020).

5 Arbitrations CAS 2017/A/5301 Sara Errani v. International Tennis Federation (ITF) \& CAS 2017/A/5302 National Anti-Doping Organisation (Nado) Italia v. Sara Errani and ITF, award of 8 June 2018, para. 216. http://jurisprudence.tas-cas.org/Shared\%20Documents/5301,\%205302.pdf (date accessed: June 13, 2020).

${ }^{6}$ Arbitration CAS 2016/O/4464 International Association of Athletics Federations (IAAF) v. All Russia Athletics Federation (ARAF) \& Ekaterina Sharmina, award of 29 November 2016, para. 194. http:// jurisprudence.tas-cas.org/Shared\%20Documents/4464.pdf (date accessed: June 13, 2020).

${ }^{7}$ Arbitration CAS 2016/O/4464 International Association of Athletics Federations (IAAF) v. All Russia Athletics Federation (ARAF) \& Ekaterina Sharmina, award of 29 November 2016, para. 194. http:// jurisprudence.tas-cas.org/Shared\%20Documents/4464.pdf (date accessed: June 13, 2020).

${ }^{8}$ Arbitration CAS 2016/O/4464 International Association of Athletics Federations (IAAF) v. All Russia Athletics Federation (ARAF) \& Ekaterina Sharmina, award of 29 November 2016, para. 190. http:// jurisprudence.tas-cas.org/Shared\%20Documents/4464.pdf (date accessed: June 13, 2020). 
by the CAS while arbitrating the CAS 2017/A/5016\&5036 when the Panel postulated that "no reason of fairness is engaged concerning an athlete found responsible for an intentional anti-doping rule violation" and then it could not find reasons for using the "fairness" exception. In this way, in cases of intentional anti-doping offenses, there is a little chance for using fairness and save results, ranking points, and other benefits. Intentional violation blocks all attempts for activation of the fairness exception, although the norm of the WADA Code does not use for it a clause as only nonintentional. But the practice of the CAS shows us that the factual clause may exist.

At the same time, the CAS is ready for interpretation of the fairness exception as actual for the anti-doping offenses with no significant fault or negligence like in the case CAS 2017/A/5301. For obtaining success sportsmen have to prove that the prohibited substance or the prohibited method had no performance-enhancing effect or it is no longer present (substance) in the sportsman's body or not using (method) for the sportsman's system ${ }^{10}$. The difficulties for sportsman's burden of proof are more than predictable.

In CAS 2006/A/1041 the Bulgarian Bobsleigh and Toboggan Federation (BBTF) disqualified the sportsmen, had offended for an anti-doping violation, for a year from the particular date. From the point of CAS view, it was not the justified decision ${ }^{11}$. In comparison, the Panel named article 10.8 of the Federation International Bobsleigh and Toboggan Rules, gives the opportunity “... where required by fairness - the period of ineligibility can be brought forward to the date of the sample collection". What should be interpreted as fairness requirements? Firstly, this case shows as some procedural fails and infringements of sportsmen's fundamental rights were made by the BBTF and its jurisdictional body. The BBTF acted (if we could say "active" in this particular case, the more actual - passive) very unhurriedly, demonstrated an inadequate level of communication with the sportsman before and during the proceedings. Along with the leisurely communication, the BBTF jurisdictional body demonstrated the excessive duration of the proceedings. Secondly, the BBTF was absent in the appeal process, which was noted by the CAS. This behavior of the BBTF cannot be skipped without the adequate reaction from the CAS. Absent of the reaction from the

\footnotetext{
${ }^{9}$ Arbitration CAS 2017/A/5016 Ihab Abdelrahman v. Egyptian Anti-Doping Organization (EGY-NADO) \& CAS 2017/A/5036 World Anti-Doping Agency (WADA) v. Ihab Abdelrahman \& EGY-NADO, award of 18 December 2017, para. 135. http://jurisprudence.tas-cas.org/Shared\%20Documents/5016,\%20 5036.pdf (date accessed: June 13, 2020).

10 Arbitrations CAS 2017/A/5301 Sara Errani v. International Tennis Federation (ITF) \& CAS 2017/A/5302 National Anti-Doping Organisation (Nado) Italia v. Sara Errani and ITF, award of 8 June 2018, para. 223. http://jurisprudence.tas-cas.org/Shared\%20Documents/5301,\%205302.pdf (date accessed: June 13, 2020).

${ }^{11}$ Arbitration CAS 2006/A/1041 Stefan Ivanov Vassiliev v. Fédération Internationale de Bobsleigh et de Tobogganing (FIBT) \& Bulgarian Bobsleigh and Toboggan Federation (BBTF), award of 28 July 2006 (operative part of 30 June 2006), para. 23. http://jurisprudence.tas-cas.org/Shared\%20Documents/1041. pdf (date accessed: June 13, 2020).
} 
respondent increases the level of difficulties for the sportsmen while presenting and commenting on the evidence. Summing up listened problems, the CAS stipulated that period of ineligibility should start retroactively on the day of testing and not from the particular date as indecision of the BBTF. What we could conclude on the issue of fairness from the CAS 2006/A/1041? This case closely to the CAS 2009/A/1782 on the question of procedural fairness: a lack of communication between the parties before and while the BBTF process and the excessive proceedings. Then it may be noticed as the derogation of the due process doctrine. Also, the absence of the BBTF while the CAS reduced the value of the de novo process because without one of the parties it is slightly difficult to investigate a factual background of the case and the sportsman has limited access to necessary evidence. In the situation of combining procedural fails (before and in process of concerning the grounds for offense) with the not bona fide behavior of the party (like the BBFT in our case) fairness dictates a more lenient approach to the sportsman's liability, including the searching the fair date of starting the disqualification.

In $C A S$ 2009/A/1782 the mentioned position of the Panel was based on ignoring by the ITF of lex mitior principle and that is why other connected procedural problems with the appealed decision had appeared. Basing on the idea of the decision we may conclude that using the procedural fairness in anti-doping offenses demands to compliance the process with fundamental rights and principles (but not principles of particular branches of law if they do not demonstrate the fundamental value).

In $C A S$ 2016/A/4772 the Panel investigates the procedural aspect of fairness criterion in the granting of the retroactive TUE. Article 6.8(b) 2015 edition of the WADA ISTUE obligates the Anti-Doping organizations for "explanation of the reason(s) for the denial". The sportsmen in this case applying for the retroactive TUE in Fédération Internationale de l'Automobile (FIA), but receiving a deny without explanation. So, the CAS has to answer the question on the legality of the mentioned decision of FIA responsible for granting the TUE body. The Panel goes to a literal interpretation of the wording of article 6.8(b), implementing to the article 4.5.5 FIA Anti-Doping Regulations: "explanation" is a reason or justification, a statement or account that makes something clear" ${ }^{\prime 2}$. Then a decision not to granting retroactive TUE shall be justified and predictable for the sportsman - formal postulating in the decision that a fairness criterion was not met cannot be considered as a necessary explanation. In conclusion, using the "fairness" as a criterion for granting retroactive TUE obligates Anti-Doping organizations to give an explanation of this conception in every particular case and restricts formal proceedings without giving to sportsman an understanding, why it is unfair to grant the retroactive TUE in his or her situation. This legal position existing near the previous decisions postulated the necessity for

12 Arbitration CAS 2016/A/4772 Diego Dominguez v. Fédération Internationale de l'Automobile (FIA), award of 12 January 2018, paras. 120, 121, 124. http://jurisprudence.tas-cas.org/Shared\%20 Documents/4772.pdf (date accessed: June 13, 2020). 
Anti-Doping organizations of motivation in the process of obtaining the retroactive TUE. In cases CAS 2009/A/1948 and CAS 2013/A/3437 the CAS similarly mentioned: "...we do consider it permissible for the Committees considering TUE applications, measured against the applicable published International Standards criteria, to refer generally to medical and scientific literature and studies which are publicly available and which one or other or both of those Committees may consider relevant and persuasive to a considered and reasoned point of view"13. Then the fairness criterion is connected with the disclosing not only suggestions of the Anti-Doping organizations and why this criterion was or was not met in the particular case of the sportsman, but also with the publicly available special literature as an essential ground of the scientific analytic that had been made.

Could a personal liability of sportsmen by the analogy used for liability of a team in a situation without the precise norm of the regulations of the sporting federation? In case CAS 2004/A/725 the International Association of Athletics Federation (IAAF) was concerned " $\ldots$ that both a purposive and even a literal interpretation of IAAF Rules require that the results of the gold medal-winning U.S.A. team be annulled. The proposition, it says, is straightforward: Jerome Young was ineligible to compete at the Sydney Olympic Games; his results are annulled; therefore the results of the four-some in which he ran must also be annulled; and the results achieved by the four U.S.A. team members who ran in the final race of the relay event must similarly be annulled since they only made it to the finals due to the results achieved by the U.S.A. team in earlier heats, in which Mr. Young ran"14. The situation had appeared because of absent in the IAAF Rules special provision for disqualifying the results of the team. Later to this Rules were adopted an amendment to the article, which declares, that all competitive results of the team obtained from the date the positive sample was provided or other anti-doping rule violation occurred, through to the commencement of the period of provisional suspension shall, unless fairness dictates otherwise, be annulled, with all resulting consequences for the sportsmen including the forfeiture of all titles, awards, medals, points and prize, and appearance money. But the cited norm was added after the case had appeared. The question was, is it possible by analogy using the disqualification of the results and other benefits of the sportsmen as a ground for the same negative aftermaths? The CAS decides that a "fairness consideration" in the exception "unless fairness dictates otherwise" shows

13 Arbitration CAS 2009/A/1948 Robert Berger v. World Anti-Doping Agency (WADA), award of 23 March 2010, para. 97. http://jurisprudence.tas-cas.org/Shared\%20Documents/1948.pdf (date accessed: June 13, 2020); Arbitration CAS 2013/A/3437 International Shooting Sport Federation (ISSF) v. World Anti-Doping Agency (WADA), award of 18 December 2014 (operative part of 4 August 2014), para. 157. http://jurisprudence.tas-cas.org/Shared\%20Documents/3437.pdf (date accessed: June 13, 2020).

14 Arbitration CAS 2004/A/725 United States Olympic Committee (USOC) v. International Olympic Committee (IOC) \& International Association of Athletics Federation (IAAF), award of 20 July 2005, para. 8. http://jurisprudence.tas-cas.org/Shared\%20Documents/725.pdf (date accessed: June 13, 2020). 
us the aim of the norm and a circle of subjects for whom it is constructed. So, “... absence of a "fairness consideration" in the rule makes it even less likely that it was intended to apply, by implication, to teams as well as to individual"15. Like in CAS 94/129 the Panel postulated that every norm of a sporting federation must be precise and understandable for the subjects and it is the one way to their applying shall be predictable ${ }^{16}$.

What we could resume from the CAS 2004/A/725? Firstly, fairness exception (the CAS named it "fairness consideration") in the norms of negative impacts on sportsman and teams blocks liability of sports subjects by an analogy like in the considered decision. Then, it shall be unfair bringing the team to the liability when the norm does not give any information about aftermaths and negative effects for the team's sporting results and benefits in case of liability of the team's members. On the other hand, fairness shows us if it legal or not to construct a norm for "strict liability" (we mean without fault or negligence) for the results and other benefits of teams without the fairness exception. The IAAF tried to do so and failed to legalize the attempt. The CAS found that the absence of the "fairness consideration" as a norm for the results and benefits of sportsman in the regulations of sports federation may be justified (although it is utmostly discussible for us), what cannot be said in case of team's liability for their sportsmen's offense. In CAS 2004/A/725 the Panel gives us an explanation, not of the procedural fairness, but a substantial one in anti-doping violations cases.

\section{The "fairness criterion" in cases of obtaining the retroactive TUE.}

In case of obtaining the retroactive TUE under the 2015 edition WADA ISTUE, it is necessary to understand the meaning of the official comment to the article 4.3(d) preventing from appeal a decision on pro et contra grounds. This does not mean a restriction for challenging at all. The article blocks attempts to replace the fairness expertise in a particular case with that of $\mathrm{CAS}^{17}$. The decision on or against the fairness in obtaining the retroactive TUE must be grounded on medical investigation and research but not on legal ideas and principles. On the other hand, if the fairness was not founded in sportsman situation, CAS has jurisdiction on the ground that the decision not to grant the retroactive TUE was not arbitrary or demonstrates

\footnotetext{
15 Arbitration CAS 2004/A/725 United States Olympic Committee (USOC) v. International Olympic Committee (IOC) \& International Association of Athletics Federation (IAAF), award of 20 July 2005, para. 17. http://jurisprudence.tas-cas.org/Shared\%20Documents/725.pdf (date accessed: June 13, 2020).

16 Arbitration CAS 2004/A/725 United States Olympic Committee (USOC) v. International Olympic Committee (IOC) \& International Association of Athletics Federation (IAAF), award of 20 July 2005, para. 20. http://jurisprudence.tas-cas.org/Shared\%20Documents/725.pdf (date accessed: June 13, 2020).

${ }^{17}$ See Arbitration CAS 2016/A/4772 Diego Dominguez v. Fédération Internationale de l'Automobile (FIA), award of 12 January 2018, para. 99. http://jurisprudence.tas-cas.org/Shared\%20Documents/4772. pdf (date accessed: June 13, 2020).
} 
"grossly disproportionate, irrational or perverse or otherwise outside of the margin of discretion, or taken in bad faith or without the due process rights provided to the athlete" 18 . So, the expertise of a decision not to obtain a retroactive TUE using the appeal proceedings is necessary actual for protecting fundamental legal grounds of a decision, influencing on rights of a sportsman.

What happens when the Anti-Doping Organizations fall to demonstrate the legal grounds of their decisions on offense of anti-doping violations, although not connected with the question of pretending for retroactive TUE? We predict that such legal failings are common in their aftermath in cases on issues of anti-doping violations or accessing for retroactive TUE. As was mentioned in the CAS 2009/A/1782 decision the Panel finds "although the ITF knew of the adverse analytical findings, it chose not to inform Mr. Filippo Volandri and to let the latter take part in 19 tournaments before formally charging him with a doping offense. Such a long period is unacceptable and incompatible with the intention of the anti-doping regime that matters should be dealt with speedily"19. In this case, the Anti-Doping Organization (ITF) has been felt asleep for a very long time (more than 6 months) and then comes back with the questions to the sportsmen about his sample, period of using the inhaler with the substance and the number of puffs. The ITF request could not be satisfied due to the lasting period before, but the organization brings the sportsmen to a liability. The behavior of the ITF corroborates disregarding the fundamental rights of the sportsmen in question "to be or not to be" a liability and how stronger it has to be: the right to a fair trial and the principle of equal treatment and the lex mitior principle. Accordingly, the CAS did not find a legal basis for the decision of the ITF and emphasized that the fairness required a more lenient sanction and confirmed the sportsman's results, ranking points, and the prize money with the exception the Manerbio tournament when his sample to anti-doping was positive. The Panel noticed: “... the ITF Tribunal, applying the lex mitior principle, accepted that salbutamol is a specified substance and that it had not been used to enhance sports performance or to mask the use of a performance-enhancing substance. It held that the Player was at fault for inhaling too much salbutamol. It found fair not to disqualify the Player's results (including ranking points and prize money) obtained before the Manerbio tournament, as he was not aware of any problem arising from the test done at the 2008 edition of the Indian Wells tournament. "However, by 18 August 2008 when the player next competed at Manerbio, he had had sufficient time to obtain some advice about the adverse A

\footnotetext{
${ }^{18}$ Arbitration CAS 2016/A/4772 Diego Dominguez v. Fédération Internationale de l'Automobile (FIA), award of 12 January 2018, para. 102. http://jurisprudence.tas-cas.org/Shared\%20Documents/4772.pdf (date accessed: June 13, 2020).

19 Arbitration CAS 2009/A/1782 Filippo Volandri v. International Tennis Federation (ITF), award of 12 May 2009, para. 55. http://jurisprudence.tas-cas.org/Shared\%20Documents/1782.pdf (date accessed: June 13, 2020).
} 
sample result, including on the question of whether to cease competing"20. Then the "fairness" promulgated by the CAS as procedural fairness in cases of sportsmen's liability on anti-doping violations, when fundamental rights and principles are corroborated in litigation. Reinstated the sportsmen in rights on a basis of procedural fairness obligates the CAS to issue a de novo decision, demonstrates a connection between the "fairness" and a necessary sanction, or without liability at all.

\section{Conclusion}

The "fairness exception" was constructed by the WADA on a model of the presumption that sportsmen must suffer the deterring negative aftermaths. But this presumption is rebuttable if he or she has special factual circumstances. Then, if he or she could prove the mentioned circumstances it will be possible to postulate a fair decision. And a level of discretion is quite high, the well-motivated decision for or against using the exception has similar chances to be positively reviewed by the CAS. In turn, the CAS has the full power to formulate does the exception exists in the particular case or not. The little worry has appeared because of the strictest approach of the CAS on cases of intentional and without significant fault or negligence. As we have demonstrated, practically there is no room for the chance of exception for a sportsman, offended in an intentional (with fault) anti-doping violation. But this does not directly follow from the wording of the WADA Code. Do not forget that proving the intentional offense is not an easy task. For this, the Anti-Doping Organizations and the CAS use the standards of comfortable satisfaction (when the burden of proof lies on an Anti-Doping Organization) and balance of probabilities (when the burden of proof on a sportsman). Both standards are not the strongest one, it is not beyond any reasonable doubt standard. What would be with fairness in the context of a mistake on intentional violence that may be the non-intentional? Appears that it is time for unambiguity and CAS should not be so unequivocal about no chances for "fairness exception" in cases of "intentional" offenses. What is real, that the CAS in revised decisions does no propose at least basic features of "fairness exception". This negatively will influence on applying the equal treatment principle in future cases of proving by sportsmen this exception - the sportsman could not find a point in the line of "fairness" for comparison between two or more cases.

The "fairness criterion" in obtaining the retroactive TUE is not a question for the jurisdictional bodies or the CAS. This issue is not a legal one and needs special knowledge and then could not be revised by the CAS as an arbitral Panel of lawyers. Nonetheless, the CAS has full power to find out does procedural fairness is observed by the Anti-Doping Organizations. In "procedural fairness" we also include precision and justification of the decision for obtaining or not the retroactive TUE. Sportsmen

${ }^{20}$ Arbitration CAS 2009/A/1782 Filippo Volandri v. International Tennis Federation (ITF), award of 12 May 2009, para. 56. http://jurisprudence.tas-cas.org/Shared\%20Documents/1782.pdf (date accessed: June 13, 2020). 
should easily and without broad interpretation understand the factual grounds for or against his application for the retroactive TUE. At the same time the "fairness criterion" should comply with the fundamental rights and the fundamental law principles. This dictates by the influence of "fairness exception" on to the "fairness criterion".

We agree with some sports lawyers disappointed in the issue of undefined "fairness" as a criterion for applying the retroactive TUE ${ }^{21}$. With that, the "fairness" in anti-doping cases is broader, than only he "fairness exception" and the "fairness criterion". Notwithstanding the WADA keeps silent in the content of the Code about fairness as a direct fundamental principle of investigation and dispute resolution, it could not be interpreted as an absence. The CAS is not also wordy on this issue. But indirectly we founded in CAS cases that fairness is a necessary part of the due process and, then, an essential element of a natural justice doctrine. It is a little chance for meeting in the future versions of the WADA ISTUE a substantial content of the "fairness criterion" for the retroactive TUE.

\section{References}

1. Arbitration CAS 2004/A/725 United States Olympic Committee (USOC) v. International Olympic Committee (IOC) \& International Association of Athletics Federation (IAAF), award of 20 July 2005. http://jurisprudence.tascas.org/Shared\%20Documents/725.pdf (date accessed: June 13, 2020).

2. Arbitration CAS 2006/A/1041 Stefan Ivanov Vassiliev v. Fédération Internationale de Bobsleigh et de Tobogganing (FIBT) \& Bulgarian Bobsleigh and Toboggan Federation (BBTF), award of 28 July 2006 (operative part of 30 June 2006). http://jurisprudence.tas-cas.org/Shared\%20Documents/1041.pdf (date accessed: June 13, 2020).

3. Arbitration CAS 2009/A/1782 Filippo Volandri v. International Tennis Federation (ITF), award of 12 May 2009. http://jurisprudence.tas-cas.org/ Shared\%20Documents/1782.pdf (date accessed: June 13, 2020).

4. Arbitration CAS 2009/A/1948 Robert Berger v. World Anti-Doping Agency (WADA), award of 23 March 2010. http://jurisprudence.tas-cas.org/Shared\%20 Documents/1948.pdf (date accessed: June 13, 2020).

5. Arbitration CAS 2013/A/3437 International Shooting Sport Federation (ISSF) v. World Anti-Doping Agency (WADA), award of 18 December 2014 (operative part of 4 August 2014). http://jurisprudence.tas-cas.org/Shared\%20 Documents/3437.pdf (date accessed: June 13, 2020).

6. Arbitration CAS 2016/A/4772 Diego Dominguez v. Fédération Internationale de l'Automobile (FIA), award of 12 January 2018. http://jurisprudence.tas-cas. org/Shared\%20Documents/4772.pdf (date accessed: June 13, 2020).

7. Arbitration CAS 2016/O/4464 International Association of Athletics Federations (IAAF) v. All Russia Athletics Federation (ARAF) \& Ekaterina Sharmina,

${ }^{21}$ Greene Paul, Kaiser Matthew. How athletes 'rights can be better protected when it comes to retroactive Therapeutic Use Exemptions, The International Sports Law Journal, No. 19, 2019, p. 37. 
award of 29 November 2016. http://jurisprudence.tas-cas.org/Shared\%20 Documents/4464.pdf (date accessed: June 13, 2020).

8. Arbitration CAS 2017/A/5016 Ihab Abdelrahman v. Egyptian Anti-Doping Organization (EGY-NADO) \& CAS 2017/A/5036 World Anti-Doping Agency (WADA) v. Ihab Abdelrahman \& EGY-NADO, award of 18 December 2017. http://jurisprudence.tas-cas.org/Shared\%20Documents/5016,\%205036.pdf (date accessed: June 13, 2020).

9. Arbitrations CAS 2017/A/5301 Sara Errani v. International Tennis Federation (ITF) \& CAS 2017/A/5302 National Anti-Doping Organisation (Nado) Italia v. Sara Errani and ITF, award of 8 June 2018. http://jurisprudence.tas-cas.org/ Shared\%20Documents/5301,\%205302.pdf (date accessed: June 13, 2020).

10. Greene Paul, Kaiser Matthew. How athletes'rights can be better protected when it comes to retroactive Therapeutic Use Exemptions, The International Sports Law Journal, No. 19, 2019, pp. 29 - 37.

11. WADA ISTUE 2015. https://www.wada-ama.org/en/resources/therapeuticuse-exemption-tue/international-standard-for-therapeutic-use-exemptions-istue (date accessed: June 13, 2020).

12. WADA ISTUE 2021. https://www.wada-ama.org/en/resources/the-code/2021international-standard-for-therapeutic-use-exemptions (date accessed: June 13, 2020).

13. World Anti-Doping Code 2015. https://www.wada-ama.org/sites/default/files/ resources/files/wada_anti-doping_code_2019_english_final_revised_v1_ linked.pdf (date accessed: June 13, 2020).

14. World Anti-Doping Code 2021. wada-ama.org/sites/default/files/resources/ files/2021_code.pdf (date accessed: June 13, 2020).

\section{(Footnotes)}

1. World Anti-Doping Code 2015. https://www.wada-ama.org/sites/default/files/ resources/files/wada_anti-doping_code_2019_english_final_revised_v1_ linked.pdf (date accessed: June 13, 2020).

2. World Anti-Doping Code 2021. wada-ama.org/sites/default/files/resources/ files/2021_code.pdf (date accessed: June 13, 2020).

3. World Anti-Doping Code 2015. https://www.wada-ama.org/sites/default/files/ resources/files/wada_anti-doping_code_2019_english_final_revised_v1_ linked.pdf (date accessed: June 13, 2020).

4. World Anti-Doping Code 2021. wada-ama.org/sites/default/files/resources/ files/2021_code.pdf (date accessed: June 13, 2020).

5. World Anti-Doping Code 2015. https://www.wada-ama.org/sites/default/files/ resources/files/wada_anti-doping_code_2019_english_final_revised_v1_ linked.pdf (date accessed: June 13, 2020).

6. World Anti-Doping Code 2021. wada-ama.org/sites/default/files/resources/ files/2021_code.pdf (date accessed: June 13, 2020). 